\title{
The Eight Modes of Local Governance in West Africa
}

\author{
Jean-Pierre Olivier de Sardan
}

\begin{abstract}
Used in an analytical and non-normative way, the concept of governance may be taken to refer to any organised method of delivering public or collective services and goods according to specific logics and norms, and to specific forms of authority. This article applies the concept to analysis of local arenas in which public goods and services are delivered or co-delivered in Niger and other countries of West Africa. The analysis proposes eight 'modes of local governance' and describes their main characteristics drawing on fieldwork evidence collected over an extended period. Chiefly, associational, municipal (municipal council), project-based, bureaucratic, sponsorship-based, religious and merchant modes of governance are distinguished. The article concludes by defining and delimiting a concept of local political culture, referring to a set of shared modern practices and representations relating to the practical operation of modes of local governance in specific local arenas.
\end{abstract}

\section{Introduction: governance and the delivery of public goods and services}

'Governance' is a very plurivalent term, used at a number of different levels and covering objects of a variety of types. ${ }^{1}$ It is not universally recognised in the social sciences. Many commentators have criticised the notion of governance for being 'polluted' by its normative definitions (developed in particular by the World Bank, a disciple of 'good governance' strongly tinted with neoliberal ideology), ${ }^{2}$ and/or to mask a 'depoliticisation' of public affairs to the benefit of a purely technocratic vision, which is either illusory or misleading (Abrahamsen 2002; Hermet et al. 2005). But governance may be conceived in a radically different way, without normative or ideological judgements, as associating the managerial as well as the political dimensions of public or collective actions (Blundo and Le Meur 2009).

Taking the concept of governance in a purely descriptive and analytical sense, we can define it as any organised method of delivering public or collective services and goods according to specific logics and norms, and to specific forms of authority. Any organised form of this delivery, operating according to specific norms, and implementing specific logics, can then be considered to be a mode of governance.
Our definition focuses on a specific function of collective action, authority or regulation which for a long time was associated with the state, but which today can be implemented by other types of players and institutions. The delivery of public or collective services and goods can be carried out in a liberal or bureaucratic manner, centralised or decentralised, clientelist or despotic, formal or informal, and driven by the market or by the state. It can be either efficient or not, delivering high-quality goods or services or not. It may involve any level of society and the state. Furthermore, the players (or organisations) which deliver public or collective services and goods are more and more numerous, particularly in Africa. The modes of governance there have become very varied, which opens up the scope of analysis even more: 'There is no longer any public service in Africa whose delivery does not include the greater or lesser involvement of the four following instances: the state administrative services, the development administration (NGOs and international agencies), the "community-type" organizations (from associations to the municipal council), and private operators' (Blundo and Le Meur 2009).

Our definition of governance enables us, therefore, to complement traditional 
anthropological approaches to the state in Africa. For the most part, these approaches have ignored the role of the state as a deliverer or co-deliverer or manager/co-manager of goods and services. ${ }^{3}$ The notion of the 'delivery state' can also be applied to local arenas, where institutions, powers and players, united by 'multiplex' ties (Gluckman 1955), confront each other on a daily basis and in concrete interactions around the delivery function. ${ }^{4}$ The coexistence of many modes of local governance seems to us to be a central characteristic of Niger as well as many African countries. The process of 'piling up' types of power in local arenas (Bierschenk and Olivier de Sardan 1998) has become generalised: when a new form of political authority is set up (either by the state or by development agencies) it does not substitute for the layers of institutionality already in place but adds to them. This is what gives a village power structure its polycephalous character. There are layers of power and legitimacy dating from different periods which all coexist in the same sociopolitical space, displaying a complex mixture of mutual recognition and blind competition, of tolerance and masked rivalry.

The analysis we propose of eight 'modes of local governance' is based first and foremost on a body of empirical data collected by Laboratoire d'Etudes et de Recherches sur les Dynamiques Sociales et le Développement Locale (Lasdel) researchers over a number of years as part of a research programme on local powers and decentralisation in Niger. ${ }^{5}$ This research has led us to distinguish eight distinct modes of local governance which we call, respectively: chiefly, associational, municipal, project-based, bureaucratic, sponsorship-based, religious and merchant.

Although we have observed them in most detail in Niger, these modes are not only present in Niger. Most Francophone African countries present similar characteristics (naturally with some important differences: Senegal has experienced decentralisation since 1973; the system of administrative chiefs was never 'abolished' in Niger while it was in Mali and Benin, etc.). It also appears to us that, in Anglophone countries, despite obvious differences (British indirect rule, for example, and its systematic ethnic policies; or the existence of strong indigenous economic dynamics in Ghana or Nigeria), the general framework set out here remains essentially valid, and can therefore serve as a basis for discussion with the aim of characterising these various modes of local governance in broader terms. Certain of these modes of local governance are the direct successors to the colonial period, while others arise from post-independence political upheavals or from development policies driven from the North. All, however, are the product of original and composite forms of public or collective action and of interactions with users. All undergo continual adjustments.

\section{The 'chiefly' mode of local governance}

The administrative system of chiefs was a fundamental institution of the colonial state apparatus, found throughout Africa, and was the main form of local power, in the service of colonisation, for more than 60 years. It was inspired by various pre-colonial institutions, from which it was supposed to derive its legitimacy. However, these 'administrative chiefs' (we call them this to distinguish them from pre-colonial chiefs) had only a little in common with the varied and heterogeneous political structures of the pre-colonial era, even if they took over their symbolic attributes and if the holders of the positions were often descended from pre-colonial aristocracies. They were in all cases, agents of the colonial state, their main function being to provide an interface between the colonial despot and the populace (Olivier de Sardan 1984; Mamdani 1996).

After independence, the system of chiefs was often attacked, or even abolished, by the new regimes, in particular those which assumed a socialist orientation. But it has never completely disappeared from the political landscape. With democratisation, it has even returned to the forefront of the local scene, at least symbolically, presenting itself as 'traditional' chieftaincy (thereby obliterating its colonial roots), but much transformed in its recruitment as well as in its functions. Today many chiefs in Niger (at least at district level, and even more at provincial level) are former civil servants, whose earlier careers often included high-level administrative tasks.

There are many variables which influence the roles performed by the innumerable forms of chieftaincy found across the continent today. 
Sometimes the modern state delegates to chieftancy certain powers of arbitration, justice and financial regulation, while elsewhere chiefs' functions are purely informal or belong mainly to a certain political folklore. Nevertheless, the chiefly mode of local governance in West Africa today presents some shared characteristics, including among others: patrimonialism; predation and corruption; patronage; absence of real accountability to the people (to which one might add aristocratic ostentation; the confusion of powers, internecine rivalry; and the defence of an aristocratic and patriarchal ideology). ${ }^{6}$

The chief's personal resources and expenditure and office resources and expenditure are officially (not informally) confused: that was common practice during the colonial period with the official backing of the state, and it is still the case today. The chief in the best cases only receives from the state an 'allowance', and must therefore finance his official responsibilities from his own income. Yet, he has a 'position to maintain' as well as services to provide and his role requires a great deal of expenditure. Alms and gifts, providing help, supporting emissaries, travel and visits, welcoming visitors: he must continually reallocate, give, distribute. The chief very officially finances 'out of his own pocket' activities linked to his function, and there is therefore complete confusion between office expenditure and personal expenditure: that is true 'patrimonialism'.

In Francophone Africa, the canton chief had always enjoyed a great deal of toleration from the colonial authorities, allowing him to raise taxes known as 'customary' and other 'contributions' or 'traditional' (often neo-traditional) tributes from those he administered. But the scale of such collection had significantly fallen by the eve of independence. The taxes became to a great extent symbolic, without necessarily being negligible. Today, for chiefly governance, the acquisition of revenue is a decisive matter. The chief finds new resources in the growing vernalisation and commodification of agricultural land, by selling land himself, or by taking a commission or under-the-table payments to guarantee sales or to adjudicate in disputes.

On the other hand, the chiefs redistribute a large part of these 'informal' resources to their dependants, their court and some of their subjects. They should be generous, and help people in need of assistance. The chief maintains a complete network of clients and practices various forms of patronage. Richness in men, like richness in assets (and the permanent conversion of financial capital into social capital, and vice versa), are sine qua non conditions for access to the system of chiefs and the success of a 'reign'. What is more, the chief is responsible for a 'household', which provides his support personnel. He needs guards, people to represent him to higher authorities in the capital, financial resources, tax collectors to collect market dues, emissaries that he can despatch to villages, counsellors to deliver justice, and a secretary for administrative tasks and to keep the necessary records, without speaking of the inevitable hangers-on attached to his person and singing his praises. He systematically chooses his collaborators and auxiliaries among his relatives and dependants. They are rewarded by him, informally. They are only beholden to him.

The chiefs avoid any formal accountability to those they administer. They are chiefs for life, and they are therefore not subject to any control by their 'subjects'. In many countries, the major threat to them is their dismissal by the central authorities, if they displease them too much, which doubtless explains why the chiefs have, in the great majority of cases, favoured the incumbent regime.

\section{The 'associational' mode of local governance}

Introduced by the development agencies from the North to provide for the operation and management of the infrastructures financed by them, this mode of governance has been significant over at least the last 20 years, and sometimes much more (in the case of the cooperatives, for example). Development cooperation agencies and NGOs required the setting up of an institutional architecture based on the Western associational model as a conditionality of their local intervention. As a result, such structures are widely distributed in all African countries, with the same core elements almost everywhere regardless of region, sector or donor: the setting-up of community-based organisations (or cooperatives, development associations, etc.), elections of representatives, establishment of management committees, the designation of an executive board, written accounts and annual general 
meetings. The system is more or less pyramidshaped (village councils, district committees, regional boards, etc.). Often, the Northern development agencies require a certain quota of women in the various offices and committees, in the name of a policy of empowerment. This institutional architecture is founded on a few keywords which characterise the type of governance which it aims to promote: public interest, community participation, transparency, accountability, partnership, promotion of women and training for democracy.

This associational mode of local governance is fundamentally an import, promoted and guided over an extended period by the various kinds of development institutions from the North (international organisations, bilateral or multilateral cooperation, development banks, small and large NGOs), and steered from a distance by them. ${ }^{7}$ Another characteristic of this institutional architecture is its combination of lavishness and ephemerality. The numerous external interventions are not coordinated, so each creates its own 'committees' as it sees fit across the country. This means that every important village has a good dozen associational management structures, each independent of the others. But the life of these structures depends on the resources and the power granted by the providers of the funds, giving them a

fundamentally transient nature. When a development project comes to an end, and all projects reach an end after a few years, the associations which it has set up also disappear.

This picture, in which the bulk of the local associational world delivering services depends directly or indirectly on development aid, has one major exception. In the sectors of plantation economy or export cultivation (e.g. cotton, coffee, cocoa), strong associations of producers have existed for a long time (based on the surpluses generated and intensive technical management). In this case, the associations of producers, although they have been implemented and supported by development agencies, deliver services on the basis of internal rents, which they control, while other associations linked to the development agencies are sub-contractors of an external rent (the 'development rent'), controlled in the North. We might therefore see in this, a specific sub-mode of governance, an important variant of the associational mode.
The associational world, especially in its informal dimensions, is of course much more diversified than this account suggests (it includes, for example, home-town associations, youth associations or specific age groups, tontines [savings and loan circles], funeral groups, vigilantes, etc.). Some of them deliver services in their own manner, without being helped by development agencies. But we will not take those into account in this article, focusing on the model imported by the development agencies, which more or less deliver everywhere the same services in the same manner: wells, grain mills, credit, seeds, market gardening, etc.

Over the years and successive projects and waves of promoters, the imported model has been 'appropriated' by the target populations, becoming an essential part of the local institutional landscape. However, this 'appropriation' of associational governance has not really followed the direction anticipated by the development agencies, far from it. For there are two types of appropriation, 'ideal appropriation' (the kind dreamed of in project documents) and 'real appropriation' (the kind actually undertaken by the local people).

The first would entail the internalisation of the imported model by the people involved. That is, based on the scenario promoted by the development operators, the associational model slowly becomes part of village reality, the transplant 'takes', the imported standards are adopted, democratic ideology is quietly incorporated into the local political culture, little by little the model's required management procedures come to be routinely applied by local players, and the system is reproduced spontaneously following the departure of the 'project'.

The second kind of 'appropriation', the one which passes a reality check, is much more complex. It involves a move away from formal rules and the following of practical norms with quite a different content, operating on lines which have multiple relationships with the assigned goals, and bring into play social mechanisms which are largely opaque to external actors. The way associational structures operate is actually quite different from what their Western designers planned and their local promoters had in mind. 
Thus, elections are often replaced by appointments based on consensus or remote control by the chief. Annual general assemblies and committee meetings do not take place on the expected dates, far from it. Accounts are not provided, and management remains opaque. Funds which are accumulated in the community coffers are 'borrowed' (owing to an 'overmonetarisation' of daily life, i.e. huge pressure for cash) (Olivier de Sardan 1999; 2008a). ${ }^{8}$ Accusations of hijacking are omnipresent, but the presumed authors are not punished. When 'projects' impose a rule of voluntary work for positions on associational boards or management committees, chairmen or treasurers bitterly complain about this state of affairs and demand a salary. Factional-type village rivalries erupt incessantly into the daily life of the associations, which are often seen more as a device in the service of a particular group than as a common asset serving everyone.

Even if this appropriation of the model seems to be largely opportunistic, driven by the desire to capture a share of the 'development rent', it is no less real for that. It exemplifies a capacity for innovation and adaptation to the modern development context, and it has sociological consequences: the 'local brokers of development' (Bierschenk et al. 2000) become a factor in local arenas, and take their place alongside the project promoters as a new type of social mediator.

\section{The 'municipal' mode of local governance}

Long present in Senegal (1973) and introduced somewhat later in Côte d'Ivoire, the municipal mode of local governance has truly been implanted in several Francophone countries of Africa (Benin, Burkina Faso, Mali and Niger) only recently, as a result of decentralisation policies. Although largely driven by external partners, its motivations have sometimes intersected with internal political considerations (e.g. peace agreements with Tuareg rebels in Mali and in Niger).

The modalities of these decentralisation reforms vary quite significantly between countries, but the result is almost the same everywhere: the setting up across the whole national territory of elected municipal councils (communes), with a mayor chosen from among the councillors, which administer territorial districts with budgetary autonomy and take on various responsibilities once handled by the central state. In rural areas of Francophone countries, ${ }^{9}$ it has been a fundamental innovation, introducing unfamiliar ways of organising the delivery of public goods and services, opening up a local space of positions of power and establishing, through commune elections, a new form of accountability to all citizens. The experience in Niger, although recent, provides various lessons in terms of the operation of the municipal mode of governance, which may have some validity elsewhere.

Whether because of shifting alliances (most often unrelated to national alliances) between the parties seeking a majority, or because of factional struggles within the locally dominant party, it is very rare for a mayor to be chosen by consensus. Once elected, mayors are subject to strong and permanent internal contestation, which has resulted in many attempts to depose them.

Decentralisation has been a bonanza for political parties. It has enabled them on the one hand to establish themselves in a sustainable manner in the interior of the country (where previously they had only played a very sporadic role, and only during national elections). On the other hand, it has offered them 'fresh' positions to fill and an opening up of the political field - in other words, new categories of prominent people and new forms of political recompense. In many countries, indeed, the purpose of the decentralisation reforms was to expand the ruling party's presence at the local level and recruit new cadres, as in Côte d'Ivoire after 1985 (Crook and Manor 1998: 140).

Conversely, the national party structures are more often than not 'manipulated' by the local notables (in much the same way that 'development projects' are). They are 'using the parties' to promote their personal interests, or strengthen their own client networks, or simply to enjoy an income or pecuniary advantage. Frequently, the observed patterns of partisan loyalty, shifting alliances and political nomadism seem to stem from purely local conflicts and from long-standing factional rivalries.

Local elections are perceived as an opportunity for the voters to 'eat', in other words as a rent from which the maximum benefit must be obtained. What is sometimes termed 'electoral corruption' has thus become a central element of 
the political landscape, and decentralisation has clearly accentuated and 'democratised' this phenomenon. 'Privilegism' (the quest for privileges) and informal privatisation have also been 'decentralised'; maximisation of the benefits associated with a given function seems to be commonplace. If evidence of proven embezzlement is hard to find, suspicion and accusations are always there.

\section{The 'project-based' mode of local governance}

The term 'project' has been added to the local languages to mean all forms of development aid and structures present on a local scale, regardless of the promoter (national or international). While the project-based mode engenders, feeds and finances the associational mode described above, it also has its own independence and exists in the field in the form of an enclave or as a management, training or monitoring body.

In one sense, the project-based mode of local governance is part of the same political and management space as the bureaucratic mode of local governance and it fulfils some of its functions, either in its place, in competition with it or in addition to it. But unlike the latter, characterised by extreme poverty, it represents on the contrary an oasis of prosperity which is the envy of all public servants, whose ambition is to be hired by a project, or failing that, to be financed by it.

The project-based mode is based on sophisticated logistical infrastructures which are completely out of keeping with the social and administrative context. It represents a form of mutualisation of spectacular bureaucratic privileges, financed by a Northern agency in accordance with extra-territorial accounting and administrative procedures, all in the service of a developmental mission. A development project is both a financing agency supporting various local actors (in particular the local associations it has itself created), and a fulfilment agency, providing certain goods and services either directly or indirectly.

The managers, once essentially expatriates, are more and more frequently nationals, generally obtained from the best elements of the civil service (according to an internal 'brain drain' which has become systematic). The projects also call upon cohorts of salaried agents, recruited locally and present throughout the country, who act as the interface with local populations.

They are by definition, provisional structures, intended to enable the goods and services which they provide to become progressively delivered by local players. But when a project disappears, it normally results in the disappearance of the goods and services which it provided.

\section{The 'bureaucratic' mode of local governance}

Under the colonial regime, which created the modern state in Africa (in a markedly derogated form, particularly under the indigénat [native code] regime), the presence of the state at a local level was symbolised by the presence of the commandant de cercle (colonial official heading a native administration) and the individuals in his service. So, the bureaucratic mode of governance was essentially ab initio of a despotic kind. Security (both political and military) and fiscal and human levies (forced labour, conscription) were priority tasks, with a large margin for manoeuvre, leaving room in particular for many privileges, such as the ability to call upon intermediaries. The administrators, prefects and sub-prefects took up the baton at independence, often reproducing the same form of despotic governance. At the same time, independence saw the progressive installation in the interior of the country (at the level of small rural towns) of state's technical services: health, education, agriculture, animal husbandry, water, etc. The bureaucratic mode of local governance encompasses what we have elsewhere called the 'local state', namely the segments of the state present in the interior of the country.

With decentralisation and democratisation, a major change to the bureaucratic mode of local governance has taken place over recent years. On the one hand, the significantly named 'command' system of administration has had to break with the key characteristics of oldfashioned despotism, and to change, at least officially, into a body supporting the communes and controlling them. But, on the other hand, the current phase is marked by a great deal of friction between the mayors and the prefects or governors. The latter are keen to retain some of their prerogatives, and aim to ensure the preeminence of the local state's political administration over the mayors. For their part, the decentralised technical services, now 
stripped of much of their previous role, are attempting to reconvert themselves and become the technical support arm of the communes, with the support of foreign partners.

\section{The 'sponsorship-based' mode of local governance}

The role of sponsorship patronage has been largely underestimated and under-studied in Africa. Yet, as Bierschenk (2006: 551) clearly shows - writing about Parakou in Benin although it is also true of Niger and many other countries - the logic of sponsorship is at the heart of local (and national) political life. We could say the same for certain public or collective services which are regularly delivered in this way. The main manifestations are the construction or repair of infrastructure (religious infrastructure, village water supplies and health centres or school buildings); the paying in the name of the populations of taxes to the state or the commune or of the quotas required by projects; and food aid in the event of shortages.

The social players likely to play the role of sponsors are varied. Alongside the model of the rich trader established in the town, or in a neighbouring country (often an illiterate El Hadj), other models exist, such as that of the politician or senior civil servant who hails from the area. Temporary or permanent migrants can also undertake sponsorship initiatives. But while this sort of patron has a foothold in the village or district of origin, he generally lives elsewhere, and his sponsorship activities are a means of achieving a high profile in the local arena (either to play a role himself, or to enable 'placement' of his dependants or clients).

\section{The 'religious' mode of local governance}

The delivery of public or collective services and goods by religious bodies sometimes seems close to the sponsorship-based mode, and sometimes to the associational mode, but there are sufficient specific features to justify speaking of a religious mode of local governance. The relevant organisations include not only those of the major religions (Catholicism, Protestantism, Islam), but also different currents within the major religions (charismatic movements, Islamic brotherhoods) or those on their periphery (syncretic and prophetic churches, sects). Some forms of social action and services (education, health, humanitarian interventions) are particularly associated with this mode of governance, focusing on collective, societal extension of the charity demanded of the faithful. An ability to mobilise international networks is a feature of the religious mode of local governance. The role of charismatic leaders, supported by religious legitimacy, must also be emphasised.

\section{The 'merchant' mode of local governance}

The privatisation of certain areas of serviceprovision in favour of multinational businesses has been a strong theme in recent times as a result of international neoliberal policies. At the same time, there is increasing recourse, at local level, to private providers to deliver public or collective services and goods, often responding to other types of logic. Like the sponsorship-based and religious modes of local governance, the merchant mode is an aggregate of various practices by a heterogeneous set of players. However, these players share the feature that they have emerged from and been shaped by the everyday world of commercial exchange. Hence, the collective goods and services that they provide are paid-for services, resulting in income-generation and profit.

We might be tempted to suppose that, since it involves a commercial transaction, privatised provision is in contradiction to an approach in terms of public goods and services. Nothing is less certain. Just as sponsor-patrons and the associational sector play a public action role, so do some private operators. Decentralisation and pressure from donors have opened up a whole range of ways of delivering public or collective goods and services which are commercial but nevertheless under the communes' or the state's responsibility. They include public service outsourcing, concessions and state-controlled subcontracting.

The merchant mode of local governance must not be confused, in this respect, with the privatisations of public agencies in the large towns, which under the pressure of the International Monetary Fund (IMF) and structural adjustment programmes opened up the water, electricity or telephone markets to large international groups (Jaglin 2005).

\section{Conclusion: local political culture}

These eight modes coexist, in general, in the same political space and in the same local arenas. Yet they are not all present everywhere, and not present with the same intensity or the 
same density across administrative levels or regions. Each mode delivers a more or less wide range of goods and services, and can be more or less specialised, while many goods or services are delivered, in a manner which can be complementary or competitive, by various modes. But the most frequent configuration is the co-delivery of a good or service by actors belonging to a number of different modes (Olivier de Sardan, Niger, this IDS Bulletin).

The modes, as discussed here, are 'ideal-types'. This has two consequences. Firstly, in concrete terms, they occasionally or even regularly overlap and roles may change: a chief, a mayor, a prophet or a prefect can also undertake sponsorships. Secondly, each mode is also cut across by internal differences: a village chief can be a simple peasant without resources or followers, which is never the case for district chiefs.

We should consider also the nature of the norms which officially or publicly regulate action within modes of governance (official norms and social norms) and the discrepancies between these and the corresponding practical norms. Each mode has its own official set of official norms. Bureaucratic, municipal, project-based and associational modes are ringed by a vast network of formal, written norms and procedures, while the sponsorship-based, merchant, chiefly and religious modes derive above all from social norms (even if various legal texts more or less define their activities). Each mode also has its own set of practical norms (patterns of informal shared practices which move around, or outside of, official norms). From one mode of local governance to the next, the discrepancy between the official norms and the practical norms can vary considerably (Olivier de Sardan 2008b).

But can we not, behind the diversity of modes of local governance, identify some common crosscutting characteristics, at least for the arenas of action observed in Niger? Indeed, various types of political behaviour can be found in several modes of local governance, sometimes even in all of them. 'Informal privatisation' (paying a fee for the delivery of a service which is normally free), which may be considered to be a form of corruption (Blundo and Olivier de Sardan 2007), is an inseparable feature of the bureaucratic mode of local governance. But it is also observed in the municipal mode, the associational mode and even in the project-based mode. Patron-client relations are present everywhere, regardless of mode. The management style of the chiefs has become a point of reference for all political leadership.

These practices and representations shared by actors belonging to different modes of local governance could be conceptualised in terms of local political culture. Precise, circumscribed, empirically-based uses of the concept of 'culture' are possible without falling into the 'culturalisttraditionalist' trap, with its host of clichés, amalgams and presuppositions. Local political culture is not the political culture of the elites in the capital, neither is it the expression of 'precolonial tradition', and it obviously has nothing to do with any distinctive 'African culture'. ${ }^{10}$ Local political culture is a set of shared modern practices and representations relating to the practical operation of modes of local governance in specific local arenas. A comparative characterisation of local political cultures can therefore be envisaged, at least for Niger, in spite of the dangers of false homogenisation and generalisation.

Factionalism, clientelism, impunity, coping strategies and resourcefulness, the combination of apparent consensus and strong local conflicts, generalised suspicion, priority given to network affiliations, absence of transparency, hegemony of the merchants, opportunistic strategies in order to obtain development aid, political transhumance, vote-buying and electoral cheating, 'privilegism', ostentatious generosity, selective mutual support, Islamic legitimisations, informal privatisation, the reduction of women selected for official functions to window-dressing roles - all of these characteristics can be found, in varying but significant degrees, in local arenas in Niger. Yet neither can we exclude from this local political culture expectations of justice or equity, which are expressed for example in the strong criticisms of the behaviour of urban elites, politicians and district chiefs which feature regularly in our interviews. In other words, the unsatisfied expectations of the people about the delivery of public goods and services, and challenges to established local powers, are in our opinion part of the political culture as much as the practices generated by the modes of local governance. Neither must we neglect the forms of solidarity, the various efforts by militants, or the episodes of collective mobilisation which occur in various places. 
Local political culture, as emerging from empirical inquiries, is on the one hand a more or less shared ideological construct, latent, changing and ambivalent, crossing the different modes of local governance and interacting with them. On the other hand, it is made up of all the

\section{Notes}

1 A great deal has been written about this term, see Gaudin (2002); Baron (2003).

2 This defining text associates 'good governance' closely with the creation of an environment favourable to international businesses (World Bank 1992).

3 We note, however, the invitations from Darbon (1985, 2001) or Copans (2001) to turn in this direction.

4 On the notion of local arena, see Bierschenk and Olivier de Sardan (1997, 1998); Dartigues (1997) and more generally, Swartz (1968) and Bailey (1969).

5 See the many reports edited in Etudes et Travaux $d u$ Lasdel (www.lasdel.net/etude.php).

6 For more detailed analysis of the 'chiefly' or 'chieftancy' mode and of the 'associational mode', see Olivier de Sardan (2009).

7 Apart from the 'participationist' paradigm of the end of the 1980s, which widely extended the scope of the associational mode, we must remember the existence, from independence

\section{References}

Abrahamsen, R. (2002) Disciplining Democracy. Development Discourse and Good Governance in Africa, London: Zed Books

Bailey, F. (1969) Strategems and Spoils, Oxford: Blackwell

Baron, C. (2003) 'La Gouvernance: Débats Autour d'un Concept Polysémique', Revue Droit et Société 54: 329-51

Bierschenk, T. (2006) 'The Local Appropriation of Democracy: An Analysis of the Municipal Elections in Parakou, Republic of Benin, 2002-03', Journal of Modern African Studies 44.4: $543-71$

Bierschenk, T. and Olivier de Sardan, J.P. (1998) 'Les Arènes Locales face à la Décentralisation et à la Démocratisation: Analyses Comparatives en Milieu Rural Béninois', in T. Bierschenk and J.P. Olivier de Sardan (eds), Les Pouvoirs au Village: Le Bénin Rural entre Démocratisation et Décentralisation, Paris: Karthala

Bierschenk, T. and Olivier de Sardan, J.P. (1997) 'ECRIS: Rapid Collective Inquiry for the shared practical norms concerning collective action, power and the delivery of goods and services, regardless of whether these norms are more or less close to official norms. It is what actors of different modes of governance have in common when performing their respective roles.

and sometimes earlier (Chauveau 1994), of cooperative or community-based organisations which were also set up from the outside.

8 It was Raynaut (1977) who first drew attention to the importance of monetary circulation in the Maradi region of Niger.

9 Many of the major towns have been communes since the $1960 \mathrm{~s}$, but these were governed by appointed non-elected mayors (delegates of the central authority) until the democratisation reforms of the 1980s/90s.

10 Elsewhere, we have emphasised the central role of the colonial heritage in the modern configuration of African states (Olivier de Sardan 2004). For a critical description of 'traditionalist Africanist culturalism', see Olivier de Sardan (2010). Bierschenk does not use the term 'political culture' about elections in Benin, but instead employs the similar notion of 'political style' (2006: 567). For an analysis of political culture in Niger, see Hahonou (2010).

Identification of Conflicts and Strategic Groups', Human Organization 56.2: 238-44 Bierschenk, T.; Chauveau, J.P. and Olivier de Sardan, J.P. (eds) (2000) Courtiers en Développement: Les Villages Africains en Quête de Projets, Paris: Karthala

Blundo, G. and Le Meur, P.Y. (eds) (2009) The Governance of Daily Life in Africa: Ethnographic Explorations of Public and Collective Services, Leiden: Brill

Blundo, G. and Olivier de Sardan, J.P. (eds) (2007) Etat et Corruption en Afrique: Une Anthropologie Comparative des Relations entre Fonctionnaires et Usagers (Bénin, Niger, Sénégal), Paris: Karthala Chauveau, J.P. (1994) 'Participation Paysanne et Populisme Bureaucratique: Essai d'histoire et de Sociologie de la Culture du Développement', in J.P. Jacob and P. Lavigne Delville (eds) Les Associations Paysannes en Afrique: Organisation et Dynamiques, Paris: APAD-Karthala-IUED

Copans, J. (2001) 'Afrique Noire: Un Etat sans Fonctionnaires?', Autrepart 20: 11-26 
Crook, R. and Manor, J. (1998) Democracy and Decentralisation in South Asia and West Africa: Participation, Accountability and Performance, Cambridge: Cambridge University Press

Darbon, D. (2001) 'De l'introuvable à l'innommable: Fonctionnaires et Professions de l'action Publique dans les Afriques', Autrepart 20: 27-42

Darbon, D. (1985) 'Pour une Socio-anthropologie Administrative', Revue Française d'Administration Publique 35: 457-68

Dartigues, L. (1997) La Notion d'arène en Anthropologie Politique, Working Papers on African Societies 17

Gaudin, J.P. (2002) Pourquoi la Gouvernance?, Paris: Presses de Sciences Po

Gluckman, M. (1955) The Judicial Process among the Barotse of Northern Rhodesia, Manchester: Manchester University Press

Hahonou, E. (2010) Démocratie et Culture Politique en Afrique: En Attendant la Décentralisation au Niger, Sarrebruck: Editions Universitaires Européennes

Hermet, G.; Kazancigil, A. and Prud'homme, J.F. (eds) (2005) La Gouvernance: Un Concept et ses Applications, Paris: Karthala

Jaglin, S. (2005) Services d'eau en Afrique Subsaharienne: La Fragmentation Urbaine en Question, Paris: CNRS Editions

Mamdani, M. (1996) Citizen and Subject: Contemporary Africa and the Legacy of Late Colonialism, Princeton, NJ: Princeton University Press (trad. Fr. Karthala 2004)

Olivier de Sardan, J.P. (2010) 'Le Culturalisme Traditionnaliste Africaniste. Analyse d'une
Idéologie Scientifique', Cahiers d'Etudes Africaines 198/199/200: 419-453

Olivier de Sardan, J.P. (2009) 'Gouvernance Associative et Gouvernance Chefferiale dans les Campagnes Nigériennes', in J.P. Olivier de Sardan and M. Tidjani Alou (eds), Les Pouvoirs Locaux au Niger: En Attendant la Décentralisation, Paris: Karthala

Olivier de Sardan, J.P. (2008a) 'Introduction Thématique: La Crise Alimentaire de 2004-2005 au Niger en Contexte', Afrique Contemporaine 225: 17-38

Olivier de Sardan, J.P. (2008b) Researching the Practical Norms of Real Governance in Africa, Discussion Paper 5, London: Africa Power and Politics Programme

Olivier de Sardan, J.P. (2004) 'Etat, Bureaucratie et Gouvernance en Afrique de l'Ouest Francophone: Un Diagnostic Empirique, une Perspective Historique', Politique Africaine 96: 139-62

Olivier de Sardan, J.P. (1999) 'A Moral Economy of Corruption in Africa?', Journal of Modern African Studies 37.1: 25-52

Olivier de Sardan, J.P. (1984) Les Sociétés Songhayzarma: Chefs, Esclaves, Guerriers, Paysans, Paris: Karthala

Raynaut, C. (1977) 'Circulation Monétaire et Évolution des Structures Socio-économiques chez les Haoussas du Niger', Africa 47.2: 160-71

Swartz, M. (ed.) (1968) Local-level Politics, Chicago: Aldine Publishing Co.

World Bank (1992) Governance and Development, Washington DC: World Bank 